\title{
The Soft Skill of Fashion Student for Entrepreneurship
}

\author{
Ma'rifatun Nashikhah, Hapsari Kusumawardani \\ Department of Industrial Technology \\ Universitas Negeri Malang \\ Malang, Indonesia \\ marifatun.ft@um.ac.id
}

\author{
Mochammad Bruri Triyono \\ Department of Technology and Vocational Education \\ PPs Universitas Negeri Yogyakarta \\ Yogyakarta, Indonesia \\ bruritriyono@uny.ac.id
}

\begin{abstract}
The research aims to reveal the success of entrepreneurship student of fashion program that viewed from soft skill. The research was ex-post-facto research, with quantitative method. The results of the research show that there is a significant effect of soft skill on the success of entrepreneurship students. There are two category of soft skill, interpersonal skill and intrapersonal skill. The result of interpersonal skill data was obtained: 1) there were 4 students $(5.9 \%)$ as low; 22 students $(32.4 \%)$ as medium; 22 students $(32.3 \%)$ as high; 20 students $(29.4 \%)$ as very high. Hence, interpersonal skill students on successful of entrepreneurship in the category was high. While the intrapersonal skill resulted: 1) there were 7 students $(10.3 \%)$ low; 26 students $(38.3 \%)$ are medium; 17 students (25\%) high; and 18 students $(26.5 \%)$ high. Hence, the intrapersonal skill students on successful of entrepreneurship in the category was high.
\end{abstract}

Keywords-entrepreneurship; soft skill; intrapersonal skill; interpersonal skill.

\section{INTRODUCTION}

Based on national medium-term development plan 20152019 the number of human resources is main capital in national students. As human resources the young generation must be able to deliver a nation to progress through of vocational education. The purpose of vocational education is graduates school that readily worked and became an independent business/entrepreneur, with the mission of the vocational and training directorate is the increased services that produce the graduates school of vocational that have good skilled and good character so they can explore and establish the ability to readily worked. Students will be guided intensively to ready in global competition and having the characteristic as like Responsive and anticipation of technological progress. The goal that results are graduates of vocational school that ready to work and create an independent business and able to compete with the younger generation between nations.

The graduates of vocational school as the youth of nations have various innovations and an independent business in the global. The directorate general of the development of national in Indonesia exports [7] Said that youth generation having a significant contribution to the formation of ASEAN Economy Community 2015. The creation of good image about Indonesia was depending with youth generation that produce the product with the creativity and useful. It is indicated that the Indonesian nation must prepare young generation to adapt the global competition with special skills like soft skill in the formation of labor and become a successful entrepreneur.

Basically everyone has the potential to achieve the success. The success of life the person not only based on intelligence intellectual was shown by good technical skill, but determined by emotion intelligence associated with soft skill. The establishing character of students since early trough soft skill that expected to grow the character of a entrepreneur. The characters that implanted early, produce students have an entrepreneur spirit, ability as entrepreneur and create innovation in business. The concept of soft skill is the term of sociological that is representative from intelligence emotional. UNESCO give the concept of soft skill as expectations of a pillar education learning to be and learning together[3].

In vocational school, students are prepared to become labor that having good skilled and capable to create an independent effort by guidance of teacher with personally and groups. Based on training and guidance of management self purpose to establish soft skill students, so that students ready to communicate and create strategy to be an entrepreneur.

In this case soft skill had a role as the achievement of to the success of someone, we need to study more deeply about success entrepreneurship student of fashion program that viewed from soft skill.

\section{METHODS}

The method of the questionnaire used to collect the data vocational high school students of the class 12 at fashion program in Yogyakarta and the total of sample 68 with technique of proportional random sampling. The research was done in three vocational high school in the Yogyakarta, there are SMK Negeri 6 Yogyakarta, SMK Muhammadiyah 4 Yogyakarta, dan SMK PIRI 2 Yogyakarta.

\section{RESULTS AND DISCUSSION}

\section{A. Vocational Education}

Education in Indonesian have some level, the level of education vocational consists of basic education, secondary education and higher education. Based on concept vocational education of the Indonesian Directorate of Education and Culture, "vocational education was a secondary education and higher education, from diploma program to be a specialist, but 
secondary education in Indonesian is called vocational school [5].

Vocational education has diverse purposes. However, perhaps the four purposes that are most central to its project are educational provisions focused on (i) the preparation for working life including informing individuals about their selection of an occupation; (ii) the initial preparation of individuals for working life, including developing the capacities to practice their selected occupations; (iii) the ongoing development of individuals throughout their working life as the requirements for performance of work transform over time; and (iv) provisions of educational experiences supporting transitions from one occupation to another as individuals either elect or are forced to change occupations across their working lives [3]. Vocational education is both complex and varied. Like other forms of education, it has aims which may be combined in different ways and vary from society to society [4].

Based on that concept vocational school try to improve the skill of human resources that developed by vocational education system based on competence required by market. The preparation of students became workers that good skilled that needed by the community is established skills by soft skill. Because soft skill is personal factor from itself that will help student get the success from the working or entrepreneur. An employer not only is required to technical competence, but must have a strong character, good attitude, and other skills [6].

The importance of soft skill for student's vocational school is one effort to prepare graduates vocational school being in labor that needed in business world and industry, and became an independent entrepreneur with successfully.

\section{B. Soft Skill}

Soft skill has some meaning in some countries of the world. For example, Australia, the Australian chamber of commerce and industry and business council of Australia define these skill as employability skills, skills required not only to gain employ contribute successfully to enterprise strategic directions [12].

Five soft skills that the most needed by student are teamwork and collaboration, decision making, problem solving, time management, and critical thinking skills [13]. Soft skills not only empower the workforce in advancing career development and personal growth, also they create new opportunities and go beyond money motivation [1].

Soft skills encompass personal, social, communication, and self-management behaviours, they cover a wide spectrum: self-awareness, trustworthiness, conscientiousness, adaptability, critical thinking, organizational awareness, attitude, initiative, empathy, confidence, integrity, self-control, leadership, problem solving, risk taking and time management[15].

Illah Sailah [6] Divide soft skills in two parts are intrapersonal skills and interpersonal skills. Intrapersonal skills is a skill that set our self. Intrapersonal skills should be improved up before somebody began connect with each other.
But interpersonal skills are the skills someone who needed to connect with each other.

Soft skills refer to a broad set of skills, competencies, behaviors, attitudes, and personal qualities that enable people to effetely navigate their environment, work well with others, perform well, and achieve their goals. These skills are broadly applicable and complement other skills such as technical, vocational, and academic skill [11].

Based on opinion of the experts about the theory soft skill is skill that owned an individual from the self and deeply affect motivation someone in determining the first step begin an entrepreneur. Soft skill reference to some skill, competence, behavior, attitudes and the quality of personal that is owned by someone to achieve the goal in success.

\section{The Success of Entrepreneurship}

Every individual has the potential to achieve a success, it depends on how the man trying to reach. When it is viewed from potential vocational high school students in entrepreneurship, it is very possible to achieve the success. A key to achieve success is the introduction of potential our self and having the character entrepreneurship, that support of success of an individual business, group and whole economic development [16].

Success is a process someone to achieve a success with some risk must be solve, as an entrepreneur who success for self and useful for others (Moko Astamoen, 2008). Every an entrepreneur who succeeded having 4 basic elements [10] are: a. IQ and Skill; b. EQ and mental; c. motivation; d. experiences. Zimmerer [19] said that there are eight characteristics of an entrepreneur to success, the following:

1. Desire for responsibility

2. Preference for moderate risk

3. Confidence in their ability to success

4. Desire for immediate feedback

5. High level of energy

6. Future orientation

7. Skill at organizing

8. Value of achievement over money

The success of life for the person not only based on intelligence intellectual which is indicated by good technical skill, but also determined by emotional intelligence with soft skill. So that it can be concluded that if an entrepreneur wants to make success in entrepreneurship must have these skills which includes intelligence intellectual pertaining to solve the problems of technical. Emotional Intelligence that will help people to build the social relations in business environment and supported with creativity is the key an entrepreneur.

\section{The Importance of Soft Skill Aspects and Entrepreneurship for Fashion Program}

Vocational school (SMK) of fashion program prepared students for being in labor with good skill and develop industry of fashion became an entrepreneur. According to compass daily newspaper on the 14 march 2015 "many ways to develop industry of fashion in the country, including 
moslem fashion who in recent years' significant developments. One of these efforts is through education of vocational school fashion program. To be able to develop fashion industry, the students are provided with diverse skills".

Fashion designers will be expected to engage with previously unrelated practices to create innovative fashion design, contextualize the work, and improve industry systems. Academia is considering how to prepare graduates for this accelerated and highly unpredictable professional landscape by reimagining the future of fashion design education [8].

Future designers will acquire success not by simply how smart they are by studying traditional subjects or to those who have master technical skills [9]. It will go to those who are able to comprehend both the problem and the context of the problem and how to design or create solutions that are efficiently and aesthetically desirable for the community.

This unpredictable future is largely due to how globalized the fashion industry has become [9]. Fashion designers must become increasingly educated in the nuances of the expanding global markets, sub-cultures, available resources, and technologies. As a result, curricula are becoming increasingly influenced by ethical issues, philosophy, innovative technology, and environmental issues [8].

So far development soft skill in vocational school still not been handled as well as [18]. The understanding about entrepreneurial should not only function as be entrepreneurial that is like creativity, solve the risk, and the ability must become part of a soft skill that expected in entrepreneurship. With the development soft skill, the graduates can to have a career, in the business and industry.

The description of data from the result of this research purpose that giving the general description, data was of the spread of data obtained in the field.

The data from respondents, the lowest score was 31 and the highest score is 48 . The counting of the data using SPSS v.23, to obtain a mean value of 39.34 ; The median of 39 ; mode of 43 ; and a standard deviation of 3.752 ; with a total score of 2.675. To understand the description of soft skill on success entrepreneurship student of vocational school, counting by average score. From the result of the data was obtained the mean value of 39.34 and SD 4. So to know a tendency of soft skill on successful entrepreneurship student will based on category as follows:

TABLE I. THE CATEGORY OF SOFT SKILL

\begin{tabular}{|c|c|c|c|}
\hline The Formula & $\begin{array}{c}\text { The Range of The } \\
\text { Score }\end{array}$ & Score & Category \\
\hline $\mathrm{X} \geq \overline{\mathrm{X}}+1 . \mathrm{SBx}$ & $\mathrm{X} \geq 39+1.4$ & $\mathrm{X} \geq 43$ & Very High \\
\hline$\overline{\mathrm{X}}+1 . \mathrm{SBx}>\mathrm{X} \geq \overline{\mathrm{X}}$ & $39+1.4>\mathrm{X} \geq 39$ & $39-43$ & High \\
\hline$\overline{\mathrm{X}}>\mathrm{X} \geq \overline{\mathrm{X}}-1 . \mathrm{SBx}$ & $39>\mathrm{X} \geq 39-4$ & $35-39$ & Medium \\
\hline $\mathrm{X}<\overline{\mathrm{X}}-1 . \mathrm{SBx}$ & $\mathrm{X}<39-1.4$ & $<35$ & Low \\
\hline
\end{tabular}

Based on the calculation on category soft skill so the frequency distribution of category soft skill is as follows:

TABLE II. THE FREQUENCY DISTRIBUTION OF SOFT SKILL

\begin{tabular}{|c|c|c|c|}
\hline Score & Frequency & Percentage & Score \\
\hline $\mathrm{X} \geq 43$ & 18 & 26.4 & Very High \\
\hline $39-43$ & 19 & 27.9 & High \\
\hline $35-39$ & 24 & 35.4 & Medium \\
\hline$<35$ & 10 & 10.3 & Low \\
\hline
\end{tabular}

The result from the table category of soft skill on success entrepreneurship students of vocational school, from 68 the students were as follows: 1$)$ there are 10 students $(10.3 \%)$ as low; 27 students (35.4\%) as medium; 22 students (27.9\%) as high; and 9 students $(26.4 \%)$ as very high, so that soft skill of students on success entrepreneurship were the category of high. The detail of soft skill was consisting two sub variables there are interpersonal and intrapersonal. The description of data two sub the variable can be explained as follows:

\section{E. Interpersonal Skill}

The data from respondents, the lowest score was 17 and the highest score was 24 . The counting of the data using SPSS v.23, to obtain a mean value of 20.35 ; The median of 20 ; mode of 21 ; and a standard deviation of 2.021 ; with a total score of 1.384. To understand the description of interpersonal skill on success entrepreneurship student of vocational school, counting by average score. From the result of the data was obtained the mean value of 20.35 and SD 2. So to know a tendency of interpersonal skill on successful entrepreneurship student will based on category as follows:

TABLE III. THE CATEGORY OF INTERPERSONAL SKILL

\begin{tabular}{|c|c|c|c|}
\hline The Formula & $\begin{array}{c}\text { The Range of The } \\
\text { Score }\end{array}$ & Score & Category \\
\hline $\mathrm{X} \geq \overline{\mathrm{X}}+1 . \mathrm{SBx}$ & $\mathrm{X} \geq 20+1.2$ & $\mathrm{X} \geq 22$ & Very High \\
\hline$\overline{\mathrm{X}}+1 . \mathrm{SBx}>\mathrm{X} \geq \overline{\mathrm{X}}$ & $20+1.2>\mathrm{X} \geq 20$ & $20-22$ & High \\
\hline$\overline{\mathrm{X}}>\mathrm{X} \geq \overline{\mathrm{X}}-1 . \mathrm{SBx}$ & $20>\mathrm{X} \geq 22-2$ & $18-20$ & Medium \\
\hline $\mathrm{X}<\overline{\mathrm{X}}-1 . \mathrm{SBx}$ & $\mathrm{X}<20-1.2$ & $<18$ & Low \\
\hline
\end{tabular}

Based on the calculation on category interpersonal skill so the frequency distribution of category interpersonal skill is as follows. The result from the table category of interpersonal skill on success entrepreneurship students of vocational school, from 68 the students were as follows: 1) there are 4 students as low; 22 students (32.4\%) as medium; 22 students $(32.3 \%)$ as high; and 20 students $(29.4 \%)$ as very high, so that interpersonal skill of students on success entrepreneurship were the category of high. 
TABLE IV. THE FREQUENCY DISTRIBUTION OF INTERPERSONAL SKILL

\begin{tabular}{|c|c|c|c|}
\hline Score & Frequency & Percentage & Score \\
\hline $\mathrm{X} \geq 22$ & 20 & 29.4 & Very High \\
\hline $20-22$ & 22 & 32.3 & High \\
\hline $18-20$ & 22 & 32.4 & Medium \\
\hline$<18$ & 4 & 5.9 & Low \\
\hline
\end{tabular}

\section{F. Intrapersonal Skill}

The data from respondents, the lowest score was 17 and the highest score was 24 . The counting of the data using SPSS v.23, to obtain a mean value of 18.99 ; The median of 19 ; mode of 18; and a standard deviation of 2.091 ; with a total score of 1.291. To understand the description of intrapersonal skill on success entrepreneurship student of vocational school, counting by average score. From the result of the data was obtained the mean value of 19 and SD 2. So to know a tendency of intrapersonal skill on successful entrepreneurship student will based on category as follows:

TABLE V. THE CATEGORY OF INTRAPERSONAL SKILL

\begin{tabular}{|c|c|c|c|}
\hline The Formula & $\begin{array}{c}\text { The Range of The } \\
\text { Score }\end{array}$ & Score & Category \\
\hline $\mathrm{X} \geq \overline{\mathrm{X}}+1 . \mathrm{SBx}$ & $\mathrm{X} \geq 19+1.2$ & $\mathrm{X} \geq 21$ & Very High \\
\hline$\overline{\mathrm{X}}+1 . \mathrm{SBx}>\mathrm{X} \geq \overline{\mathrm{X}}$ & $19+1.2>\mathrm{X} \geq 19$ & $19-21$ & High \\
\hline$\overline{\mathrm{X}}>\mathrm{X} \geq \overline{\mathrm{X}}-1 . \mathrm{SBx}$ & $19>\mathrm{X} \geq 19-2$ & $17-19$ & Medium \\
\hline $\mathrm{X}<\overline{\mathrm{X}}-1 . \mathrm{SBx}$ & $\mathrm{X}<19-1.2$ & $<17$ & Low \\
\hline
\end{tabular}

Based on the calculation on category intrapersonal skill so the frequency distribution of category intrapersonal skill is as follows:

TABLE VI. FREQUENCY DISTRIBUTION OF INTRAPERSONAL SKILL

\begin{tabular}{|c|c|c|c|}
\hline Score & Frequency & Percentage & Score \\
\hline $\mathrm{X} \geq 21$ & 18 & 26.5 & Very High \\
\hline $19-21$ & 17 & 25 & High \\
\hline $17-19$ & 26 & 38.3 & Medium \\
\hline$<17$ & 7 & 10.3 & Low \\
\hline
\end{tabular}

The result from the table category of intrapersonal skill on success entrepreneurship students of vocational school, from 68 the students were as follows: 1) there are 7 students $(10.3 \%)$ as low; 26 students $(38.3 \%)$ as medium; 17 students (25\%) as high; and 18 students $(26.5 \%)$ as very high, so that intrapersonal skill of students on success entrepreneurship were the category of high.

\section{CONCLUSION}

Based on this research, it proved that soft skill effect on success entrepreneurship students, soft skill was having influence in very important part of life and determination of someone's career. In the workplace, soft skill is used to build a business to support performance an entrepreneur. The needed of soft skill, there are interpersonal of skill and intrapersonal skill that making connection between people in networking.

Soft skill is closely related with intelligence in management self, how an individual capable of the abbility to solve the problems at work. Intelligence is needed an entrepreneur to design the future business. The importance of soft skill will affect the success of someone in determining the first step begin an entrepreneur. An entrepreneur must have good soft skill that business can run well. The skills will be useful to create a good relationship between people, communicate and build cooperation with others. Students who have high soft skill would be easy to communicate and cooperate to reach success entrepreneurship.

\section{REFERENCES}

[1] Al Abduwani,T.A.R, "The value and development of soft skills: the case of oman," vol.2, Oman: International Journal of Information Technology and Business Management, 2012, Pp. 77-86.

[2] Barnawi \& Arifin, M, Schoolpreneurship, membangkitkan jiwa \& sikap kewirausahaan siswa, Yogyakarta: AR-RUZZ MEDIA, 2012.

[3] Billett, S, Vocational education purposes, traditions and prospects, London: Springer Dordrecht Heidelberg, 2011.

[4] .Clarke, L., \& Winch, C, Vocational education: international approaches, developments and systems, New York: Routledge, 2007.

[5] Depdikbud, Tantangan guru SMK abad 21, Jakarta: Direktorat Pembinaan PTK DIKMEN, 2013.

[6] Dikti, Pengembangan soft skill dalam proses pembelajaran di perguruan tinggi, Jakarta: Direktorat Akademik Jendral Pendidikan Tinggi, 2008.

[7] Ditjen PEN, ASEAN community 2015, Jakarta: Kementerian Perdagangan Republik Indonesia, 2012.

[8] Faerm, Steven, "Towards a Future Pedagogy: The Evolution of Fashion Design Education," International Journal of Humanities and Social Science, vol.2, New York:Academic, 2012, pp. 129-152.

[9] Faerm, Steven, "From classroom to design room: the transitional experience of the fashion design graduate," Centro de Estudios en Diseño y Comunicación, vol.2, New York:Academic, 2014, pp.210219.

[10] Hendro, Dasar-dasar kewirausahaan, Jakarta: Erlangga, 2011.

[11] Lippman, R., Carney \& Moore, Key" soft skills" that foster youth workforce success: toward a consensus across fields, New York: Child Trends Publication, 2015.

[12] Maclean, R.., Jagannathan, S., \& Sarvi, J, Skills development for inclusive and sustainable growth in developing asia pacific. London: Springer, 2013.

[13] Majid, S., Liming, Z., Tong, S., et al," Importance of soft skill for education and carer success," vol.2, singapor: Journal of Education, 2013, pp. 1036-1042. 
[14] Moko Astamoen, Entrepreneurship dalam perspektif kondisi bangsa indonesia, Bandung: Alfabeta, 2008.

[15] Peggy, The hard truth about soft skills, New York: HarperCollin Publisher, 2007

[16] Suryana,Y., \& Bayu, K, Kewirausahaan, pendekatan karakteristik wirausahawan sukses, Jakarta: Kencana, 2013.

[17] The daily newspaper of Harian kompas at 14 maret 2015,http://female.kompas.com/read/2015/03/14/100000720/Kini.Siswa. SMK.Tata.Busana.Tak.Hanya.Diajarkan.Menjahit
[18] Utaminingsih, Sri, “ Pengembangan Soft Skill Berbasis Karir Pada Smk Di Kota Semarang, " vol.6, Semarang: Jurnal Pendidikan Ekonomi Dinamika Pendidikan, 2011, pp. 119-133.

[19] Zimmerer, T.W, Essentials of entrepreneurship and small business management, New Jersey: Prentice-Hall, 1998. 